\title{
Croceicoccus marinus gen. nov., sp. nov., a yellow-pigmented bacterium from deep-sea sediment, and emended description of the family Erythrobacteraceae
}

\author{
Correspondence \\ Xue-Wei Xu \\ xuxw@sio.org.cn \\ Min Wu \\ wumin@zju.edu.cn
}

\author{
Xue-Wei Xu, ${ }^{1,2}$ Yue-Hong $\mathrm{Wu}^{3}{ }^{3}$ Chun-Sheng Wang, ${ }^{1,2}$ Xiao-Gu Wang, ${ }^{1,2}$ \\ Aharon Oren ${ }^{4}$ and Min $\mathrm{Wu}^{3}$ \\ ${ }^{1}$ Laboratory of Marine Ecosystem and Biogeochemistry, State Oceanic Administration, Hangzhou \\ 310012, PR China \\ ${ }^{2}$ Second Institute of Oceanography, State Oceanic Administration, Hangzhou 310012, PR China \\ ${ }^{3}$ College of Life Sciences, Zhejiang University, Hangzhou 310058, PR China \\ ${ }^{4}$ Institute of Life Sciences and the Moshe Shilo Minerva Center for Marine Biogeochemistry, The \\ Hebrew University of Jerusalem, Jerusalem 91904, Israel
}

The family Erythrobacteraceae (order Sphingomonadales, class Alphaproteobacteria) was proposed by Lee et al. (2005) based on a comprehensive phylogenetic analysis and, at present, it comprises four recognized genera: Altererythrobacter (Kwon et al., 2007), Erythrobacter (Shiba \& Simidu, 1982), Erythromicrobium (Yurkov et al., 1994) and Porphyrobacter (Fuerst et al., 1993).

\footnotetext{
Abbreviation: BChl a, bacteriochlorophyll a.

The GenBank/EMBL/DDBJ accession number for the 16S rRNA gene sequence of strain E4A9 ${ }^{\top}$ is EF623998.

Additional figures showing the phylogenetic tree based on 16S rRNA gene sequences constructed using the maximum-parsimony method, the two-dimensional TLC of the total polar lipids of strain $E 4 A 9^{\top}$ and absorption spectra of cells of strain $E 4 A 9^{\top}$ are available with the online version of this paper.
}

Members of the family Erythrobacteraceae are aerobic and produce pink, orange or yellow pigments. Ubiquinone-10 is the major respiratory quinone. Most species in the family have been isolated from various aquatic environments such as freshwater, seawater, marine mats or sediment, a hot spring, seaweed, a starfish and coral (Shiba \& Simidu, 1982; Fuerst et al., 1993; Yurkov et al., 1994; Hanada et al., 1997; Denner et al., 2002; Hiraishi et al., 2002; Rainey et al., 2003; Yoon et al., 2003, 2004a, b, 2005a, b, 2006; Ivanova et al., 2005; Kwon et al., 2007). This study focuses on the description of strain $\mathrm{E} 4 \mathrm{~A} 9^{\mathrm{T}}$, isolated from a deep-sea sediment sample. Based on the taxonomic data, it is proposed that this strain be included in a new genus within the family Erythrobacteraceae.

The deep-sea sediment samples were collected by a multicorer from the East Pacific polymetallic nodule region $\left(8^{\circ} 22^{\prime} 38^{\prime \prime} \mathrm{N} 145^{\circ} 23^{\prime} 56^{\prime \prime} \mathrm{W}\right)$ at a depth of 
$5280 \mathrm{~m}$ (temperature $2{ }^{\circ} \mathrm{C}$, salinity $34 \%$ ) from the vessel Da Yang Yi Hao. On board the ship, all sediment samples were subsampled aseptically and stored at $-20{ }^{\circ} \mathrm{C}$ until use.

Approximately $100 \mathrm{mg}$ sediment subsample was incubated for 3 days in ZoBell marine-Casamino acids (ZMCA) medium, which contained (per litre distilled water): $\mathrm{NaCl}$, $19.45 \mathrm{~g} ; \mathrm{MgCl}_{2}, 8.8 \mathrm{~g} ; \mathrm{Na}_{2} \mathrm{SO}_{4}, 3.24 \mathrm{~g} ; \mathrm{CaCl}_{2}, 1.8 \mathrm{~g} ; \mathrm{KCl}$, $0.55 \mathrm{~g} ; \mathrm{NaHCO}_{3}, 0.16 \mathrm{~g} ; \mathrm{C}_{6} \mathrm{H}_{5} \mathrm{FeO}_{7} .5 \mathrm{H}_{2} \mathrm{O}, 0.1 \mathrm{~g} ; \mathrm{KBr}$, $0.08 \mathrm{~g} ; \mathrm{CsCl}_{2}, 34 \mathrm{mg} ; \mathrm{H}_{3} \mathrm{BO}_{3}, 22 \mathrm{mg} ; \mathrm{Na}_{2} \mathrm{SiO}_{3}, 4.0 \mathrm{mg}$; $\mathrm{NaF}, 2.4 \mathrm{mg} ; \mathrm{NH}_{4} \mathrm{NO}_{3}, 1.6 \mathrm{mg} ; \mathrm{Na}_{3} \mathrm{PO}_{4}, 8.0 \mathrm{mg}$; peptone (Difco), $0.5 \mathrm{~g}$; yeast extract (Difco), $0.1 \mathrm{~g}$; and Casamino acids (Difco), $0.1 \mathrm{~g}$; pH 7.2 (ZoBell, 1941). The liquid was then plated on ZMCA agar plates using a tenfold dilution series method. After several days of aerobic incubation at $25{ }^{\circ} \mathrm{C}$, a yellow colony, designated strain $\mathrm{E} 4 \mathrm{~A} 9^{\mathrm{T}}$, was picked. The strain was purified by repeated restreaking; purity was confirmed by the uniformity of colony morphology. Unless otherwise stated, strain $\mathrm{E} 4 \mathrm{~A} 9^{\mathrm{T}}$ was maintained on rich (R) medium at $28{ }^{\circ} \mathrm{C}$. $\mathrm{R}$ medium contained (per litre distilled water): $\mathrm{NaCl}, 30 \mathrm{~g}$; $\mathrm{MgSO}_{4} .7 \mathrm{H}_{2} \mathrm{O}, 2.46 \mathrm{~g} ; \mathrm{KCl}, 1.5 \mathrm{~g} ; \mathrm{CaCl}_{2} .2 \mathrm{H}_{2} \mathrm{O}, 0.15 \mathrm{~g}$; $\mathrm{NaBr}, 0.1 \mathrm{~g} ; \mathrm{FeCl}_{2} .2 \mathrm{H}_{2} \mathrm{O}, 0.016$ g; yeast extract (Difco), $2.0 \mathrm{~g}$; peptone (Difco), $5.0 \mathrm{~g}$; and Casamino acids (Difco), $1.0 \mathrm{~g} ; \mathrm{pH} 7.2$.

The 16S rRNA gene was amplified and analysed as described previously (Xu et al., 2007b). The sequence was compared with closely related sequences of reference organisms from the FASTA and EZTAXON services (Chun et al., 2007). Sequence data were aligned with CLUSTAL $\mathrm{W}$ 1.8 (Thompson et al., 1994). Phylogenetic trees were constructed by the neighbour-joining (Saitou \& Nei, 1987) and maximum-parsimony methods (Fitch, 1971) with the MEGA3 program package (Kumar et al., 2004) and by the maximum-likelihood method (Felsenstein, 1981) with the TREEPUZZLE 5.2 program. Evolutionary distances were calculated according to the algorithm of the Kimura twoparameter model (Kimura, 1980) for the neighbourjoining method.

The almost complete 16S rRNA gene sequence (1450 nt) of strain $\mathrm{E} 4 \mathrm{~A} 9^{\mathrm{T}}$ was obtained. Comparisons with sequences from representative bacteria with validly published names indicated that strain $\mathrm{E} 4 \mathrm{~A} 9^{\mathrm{T}}$ belonged to the order Sphingomonadales. The strain was most closely related to members of the genera Altererythrobacter (94.7-96.0\% similarity), Erythrobacter (94.0-95.4\%), Erythromicrobium $(94.8 \%)$ and Porphyrobacter (94.6-95.1\%) in the family Erythrobacteraceae and moderately related to members of the genera Blastomonas (94.9\%), Novosphingobium (93.595.5\%), Sandaracinobacter (91.1\%), Sandarakinorhabdus (91.4\%), Sphingobium (91.3-92.2\%), Sphingomonas (90.495.2\%), Sphingopyxis (92.7-95.4\%), Sphingosinicella (93.1-93.2\%) and Zymononas (91.8\%) in the family Sphingomonadaceae. Phylogenetic analysis based on $16 \mathrm{~S}$ rRNA gene sequences showed that strain $\mathrm{E} 4 \mathrm{~A} 9^{\mathrm{T}}$ formed a distinct phylogenetic lineage with respect to the family
Erythrobacteraceae and could not be associated with any of the recognized genera in the family (Fig. 1). The topologies of the phylogenetic trees constructed using the maximumlikelihood and maximum-parsimony algorithms also supported the notion that the isolate could represent a genus that was phylogenetically distinct from closely related genera in the family Erythrobacteraceae (Fig. 1 and Supplementary Fig. S1, available in IJSEM Online).

The optimal conditions for growth were determined in $\mathrm{R}$ medium containing various $\mathrm{NaCl}$ concentrations $(0,0.5$, $1.0,3.0,5.0,7.5,10.0,15.0$ and $20.0, \mathrm{w} / \mathrm{v})$. The $\mathrm{pH}$ range for growth was determined by adding MES ( $\mathrm{pH}$ 5.0-6.0),

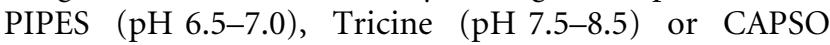
( $\mathrm{pH} 9.0-10.0$ ) to $\mathrm{R}$ medium at concentrations of $25 \mathrm{mM}$. The temperature range for growth was determined by incubating cells at various temperatures $\left(4-48{ }^{\circ} \mathrm{C}\right)$. Cell morphology and motility were examined by optical microscopy (BX40; Olympus) and electron microscopy (S260, Cambridge; JEM-1230, JEOL). Pigment absorption spectrum analysis was performed by the method described by Rainey et al. (2003) using a Beckman Coulter DU 800 spectrophotometer.

Single carbon source assimilation tests were performed using a basal medium (Kämpfer et al., 1991). The basal medium contained (per litre distilled water): $\mathrm{NaCl}, 9.0$ g; $\mathrm{MgSO}_{4} .7 \mathrm{H}_{2} \mathrm{O}, 0.5 \mathrm{~g} ; \mathrm{CaCl}_{2} .2 \mathrm{H}_{2} \mathrm{O}, 0.1 \mathrm{~g} ; \mathrm{K}_{2} \mathrm{HPO}_{4}, 1.74 \mathrm{~g}$; $\mathrm{KH}_{2} \mathrm{PO}_{4}, 1.36 \mathrm{~g}$; $\left(\mathrm{NH}_{4}\right)_{2} \mathrm{SO}_{4}, 5 \mathrm{~g}$; yeast extract (Difco), $0.02 \mathrm{~g}$; peptone (Difco), $0.02 \mathrm{~g}$; vitamin mixture solution, $1 \mathrm{ml}$; mineral salts mixture solution, $5 \mathrm{ml}$; and $25 \mathrm{mM}$ PIPES; pH 7.2. All carbon sources (w/v: $0.2 \%$ sugars; $0.1 \%$ alcohols; $0.1 \%$ organic acids; or $0.1 \%$ amino acids) were filter-sterilized before addition to the basal liquid medium. The vitamin mixture contained (per litre distilled water): biotin, $2 \mathrm{mg}$; folic acid, $2 \mathrm{mg}$; pyridoxine hydrochloride, $10 \mathrm{mg}$; riboflavin, $5 \mathrm{mg}$; thiamine, $5 \mathrm{mg}$; nicotinic acid, $5 \mathrm{mg}$; pantothenic acid, $5 \mathrm{mg}$; vitamin $\mathrm{B}_{12}, 0.1 \mathrm{mg}$; $p$ aminobenzoic acid, $5 \mathrm{mg}$; and thioctic acid, $5 \mathrm{mg}$ (Wolin et al., 1963). The mineral salts mixture contained (per litre distilled water): nitrilotriacetic acid, $1.5 \mathrm{~g} ; \mathrm{MgSO}_{4} .7 \mathrm{H}_{2} \mathrm{O}$, $3.0 \mathrm{~g} ; \mathrm{MnSO}_{4} \cdot 2 \mathrm{H}_{2} \mathrm{O}, 0.5 \mathrm{~g} ; \mathrm{NaCl}, 1.0 \mathrm{~g} ; \mathrm{FeSO}_{4} .7 \mathrm{H}_{2} \mathrm{O}$, $0.1 \mathrm{~g} ; \mathrm{CoCl}_{2} \cdot 6 \mathrm{H}_{2} \mathrm{O}, 0.1 \mathrm{~g} ; \mathrm{CaCl}_{2} \cdot 2 \mathrm{H}_{2} \mathrm{O}, 0.1 \mathrm{~g} ; \mathrm{ZnCl}_{2}$, $0.13 \mathrm{~g} ; \mathrm{CuSO}_{4} .5 \mathrm{H}_{2} \mathrm{O}, 0.01 \mathrm{~g} ; \mathrm{AlK}\left(\mathrm{SO}_{4}\right)_{2}, 0.01 \mathrm{~g} ; \mathrm{H}_{3} \mathrm{BO}_{3}$, $0.01 \mathrm{~g} ; \mathrm{Na}_{2} \mathrm{MoO}_{4}, 0.025 \mathrm{~g} ; \mathrm{NiCl}_{2} \cdot 6 \mathrm{H}_{2} \mathrm{O}, 0.024 \mathrm{~g}$; and $\mathrm{Na}_{2} \mathrm{WO}_{4} \cdot 2 \mathrm{H}_{2} \mathrm{O}, 0.025 \mathrm{~g}$ (Balch et al., 1979). Modified $\mathrm{R}$ medium was also used to confirm the assimilation of substrates. Modified $\mathrm{R}$ medium contained (per litre distilled water): $\mathrm{NaCl}, 30 \mathrm{~g} ; \mathrm{MgSO}_{4} \cdot 7 \mathrm{H}_{2} \mathrm{O}, 2.46 \mathrm{~g} ; \mathrm{KCl}$, $1.5 \mathrm{~g} ; \mathrm{CaCl}_{2} .2 \mathrm{H}_{2} \mathrm{O}, 0.15 \mathrm{~g} ; \mathrm{NaBr}, 0.1 \mathrm{~g} ; \mathrm{FeCl}_{2} .2 \mathrm{H}_{2} \mathrm{O}$, $0.016 \mathrm{~g}$; and Casamino acids (Difco), $0.01 \mathrm{~g} ; \mathrm{pH}$ 7.2. Acid production was tested using modified MOF medium supplemented with $0.5 \%$ sugars or alcohols (Leifson, 1963; $\mathrm{Xu}$ et al., 2008). Biochemical tests were performed using the methods described by Mata et al. (2002).

Fatty acid methyl esters were obtained from cells grown in $\mathrm{R}$ medium for $24 \mathrm{~h}$ at $28{ }^{\circ} \mathrm{C}$ and analysed by using GC-MS (Kuykendall et al., 1988). Isoprenoid quinones were 


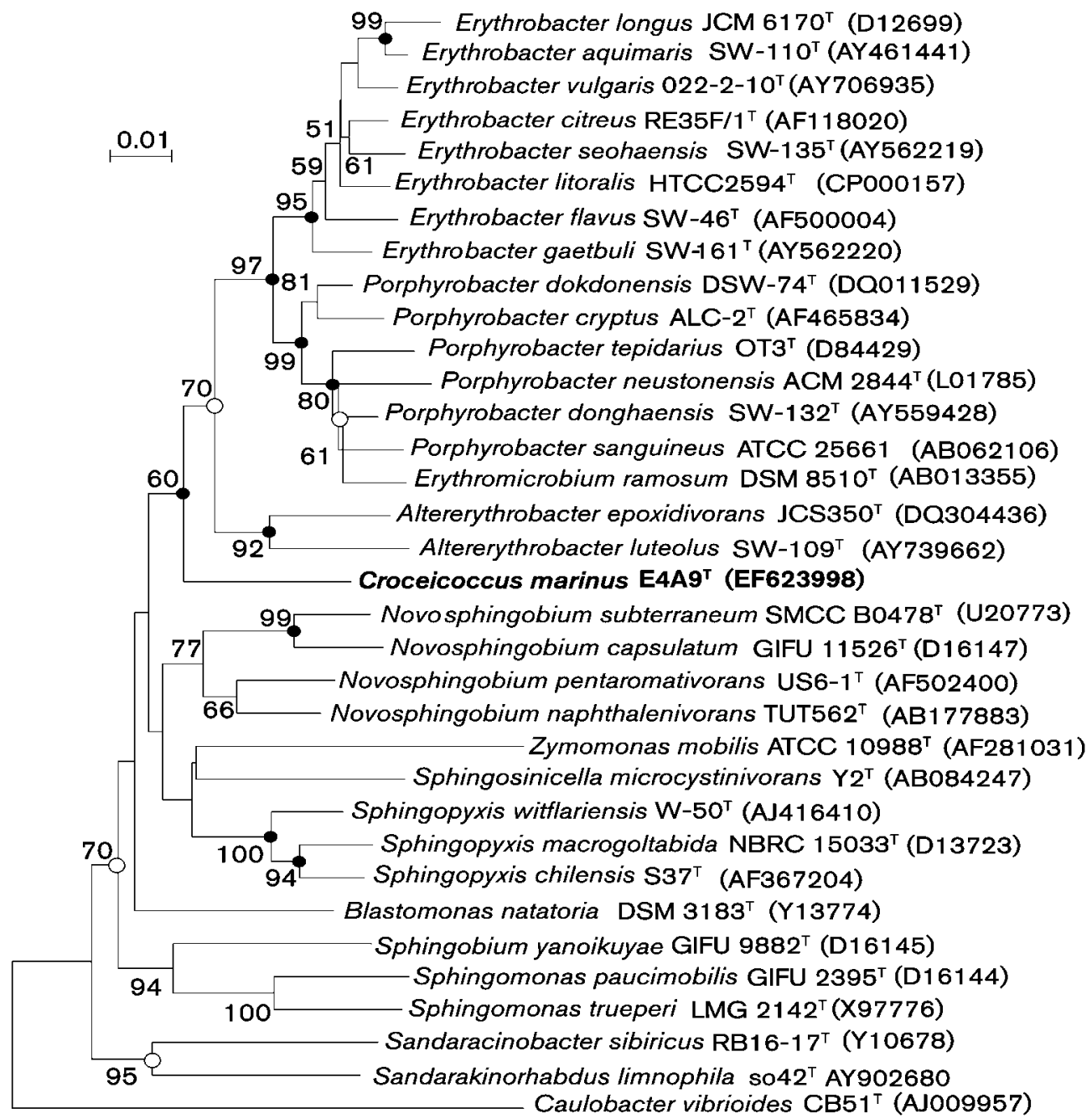

Fig. 1. Neighbour-joining tree based on 16S rRNA gene sequences showing the phylogenetic relationships between the novel isolate and related taxa. Bootstrap values are based on 1000 replicates; only values $>50 \%$ are shown. Filled circles indicate that nodes were recovered with bootstrap values $>50 \%$ in both maximum-likelihood and maximum-parsimony trees. Open circles indicate nodes were recovered with bootstrap values $>50 \%$ in the maximum-parsimony tree. Bar, 0.01 substitutions per nucleotide position.

extracted from freeze-dried cells $(200 \mathrm{mg})$ with chloroform/methanol $(2: 1)$ and analysed by reversed-phase HPLC. Total lipids were extracted by the modified method of Kamekura \& Kates (1988). Phospholipids and glycolipids were separated on silica gel plates $(10 \times 10 \mathrm{~cm})$ by TLC and analysed according to $\mathrm{Xu}$ et al. (2007a). The purified DNA was hydrolysed with P1 nuclease and the nucleotides were dephosphorylated with calf intestine alkaline phosphatase (Mesbah \& Whitman, 1989). The $\mathrm{G}+\mathrm{C}$ content of the resulting deoxyribonucleosides was determined by reversed-phase HPLC and calculated from the deoxyguanosine/thymidine ratio (Mesbah \& Whitman, 1989).

Strain E4A9 ${ }^{\mathrm{T}}$ was Gram-negative, chemoheterotrophic, facultatively aerobic, catalase-positive and oxidase-negative. Cells were motile, irregular cocci that possessed multifibrillar stalk-like fascicle structures on the cell surface (Fig. 2). An electron micrograph of negatively stained cells did not reveal flagella. Strain $\mathrm{E} 4 \mathrm{~A} 9^{\mathrm{T}}$ occurred in clusters of two to four cells (Fig. 2a). Cell division occurred via fission (Fig. 2b). The polar lipid profiles included phosphatidylglycerol and two unidentified glycolipids as the major compounds and minor to trace amounts of phosphatidylcholine and an unidentified phospholipid (see Supplementary Fig. S2, available in IJSEM Online). The major fatty acids $(>1 \%)$ of strain $\mathrm{E}_{4} \mathrm{~A} 9^{\mathrm{T}}$ were anteiso- $\mathrm{C}_{15: 0}$ $(73.3 \%)$, iso- $\mathrm{C}_{15: 0}(8.3 \%)$, iso- $\mathrm{C}_{14: 0}(7.0 \%)$, iso- $\mathrm{C}_{16: 0}$ $(4.1 \%), \mathrm{C}_{16: 0}(2.5 \%)$, anteiso- $\mathrm{C}_{13: 0}(1.8 \%)$ and anteiso$\mathrm{C}_{15: 0}(1.3 \%)$. Detailed results of the phenotypic and biochemical tests are given in the species description.

Strain $\mathrm{E} 4 \mathrm{~A} 9^{\mathrm{T}}$ could be differentiated from members of other genera of the family Erythrobacteraceae by several 


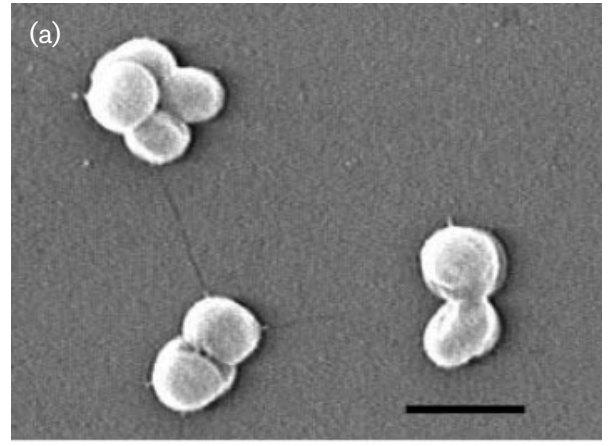

(b)

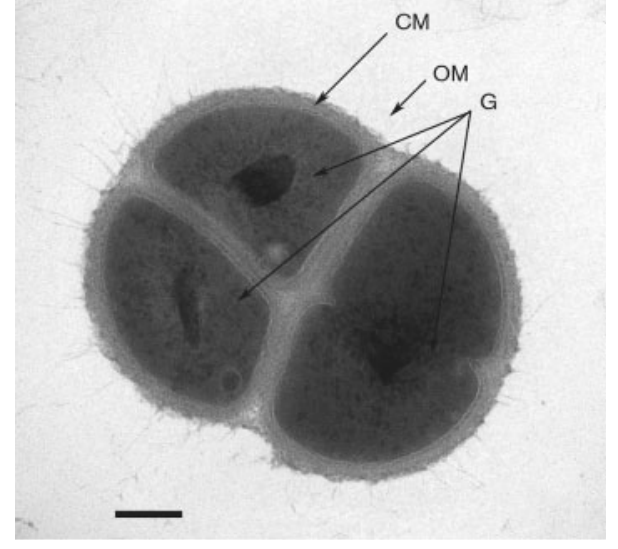

Fig. 2. Scanning electron micrograph (a; bar, $2 \mu \mathrm{m})$ and transmission electron micrograph of an ultrathin section ( $b$; bar, $0.2 \mu \mathrm{m}$ ) of exponentially grown cells of strain $\mathrm{E} 4 \mathrm{~A} 9^{\top}$ showing the unique cell division pattern. OM, Outer membrane; CM, cytoplasmic membrane; $\mathrm{G}$, intracellular granules.

phenotypic characteristics and DNA G $+\mathrm{C}$ content, as well as by its fatty acid constituents (Table 1). Members of the genera Erythromicrobium and Porphyrobacter, as well as Erythrobacter longus and Erythrobacter litoralis, synthesized bacteriochlorophyll $a(\mathrm{BChl} a)$ under aerobic conditions and displayed absorption peaks at about 800 and $870 \mathrm{~nm}$. The absence of characteristic peaks between 770 and $900 \mathrm{~nm}$ in membrane preparations and their extracts indicated that strain $\mathrm{E} 4 \mathrm{~A} 9^{\mathrm{T}}$ lacked $\mathrm{BChl} a$ and differed from most species within the family Erythrobacteraceae (see Supplementary Fig. S3, available in IJSEM Online). The DNA G $+C$ content of strain $\mathrm{E} 4 \mathrm{~A} 9^{\mathrm{T}}$ was $71.5 \mathrm{~mol} \%$, which was 11-17 mol\% higher than those of the members of the genus Altererythrobacter. The major fatty acid constituents of strain $\mathrm{E} 4 \mathrm{~A} 9^{\mathrm{T}}$ were short- and branched-chain fatty acids, unlike those found in other members of the family Erythrobacteraceae (Table 1). The biochemical characteristics and carbon source utilization patterns also clearly differentiated strain $\mathrm{E} 4 \mathrm{~A} 9^{\mathrm{T}}$ from members of other genera of the family Erythrobacteraceae (Table 1).

On the basis of the phenotypic and phylogenetic data presented in this study, strain $\mathrm{E} 4 \mathrm{~A} 9^{\mathrm{T}}$ represents a novel species in a new genus within the family Erythrobacteraceae for which the name Croceicoccus marinus gen. nov., sp. nov. is proposed.

\section{Emended description of the family Erythrobacteraceae Lee et al. 2005}

The description is identical to that given by Lee et al. (2005) with the following amendments. Gram-negative, rod-shaped or pleomorphic coccoid bacteria. Cells contain carotenoids and most species contain $\mathrm{BChl} a$.

\section{Description of Croceicoccus gen. nov.}

Croceicoccus [Cro.ce.i.coc'cus. L. adj. croceus yellow, golden; N.L. masc. n. coccus (from Gr. masc. n. kokkos) grain or berry; N.L. masc. n. Croceicoccus referring to a yellow coccoid-shaped bacterium].

Gram-negative and non-spore-forming cocci. Divide by binary division. Capable of producing multifibrillar stalklike fascicle structures on the cell surface. Contains carotenoids, but no BChl $a$. Aerobic and chemoheterotrophic. No growth occurs anaerobically in the light. Ubiquinone-10 is the major respiratory quinone. The polar lipid profiles comprise phosphatidylglycerol, two unidentified glycolipids, phosphatidylcholine and an unidentified phospholipid. The phylogenetic position is in the $\alpha-4$ subgroup of the class Alphaproteobacteria. The type species is Croceicoccus marinus.

\section{Description of Croceicoccus marinus sp. nov.}

Croceicoccus marinus (ma.ri'nus. L. masc. adj. marinus of or belonging to the sea, marine).

Shows the following characteristics in addition to those given in the genus description. Cells are motile and occur in pairs. Young cultures show pleomorphic coccoid cells $(0.8-1.0 \mu \mathrm{m})$. Colonies on complex agar containing peptone, Casamino acids and yeast extract are 1-2 mm in diameter, circular, smooth, elevated, opaque and yellowpigmented after $48 \mathrm{~h}$ at $25{ }^{\circ} \mathrm{C}$. The methanol-soluble pigment is characterized by absorption maxima at 399, 423 and $452 \mathrm{~nm}$. Growth occurs at $\mathrm{NaCl}$ concentrations of $0-10.0 \%(\mathrm{w} / \mathrm{v})$, with optimum growth at $0-1.0 \%(\mathrm{w} / \mathrm{v})$ $\mathrm{NaCl}$. Grows at $\mathrm{pH} 6.0-9.0$ and $4-42{ }^{\circ} \mathrm{C}$; optimum growth is at $\mathrm{pH} 7.0$ and $25{ }^{\circ} \mathrm{C}$. Oxidase-negative and catalasepositive. Does not grow on MacConkey agar or cetrimide agar. Aesculin, casein, gelatin, starch, Tween 20, Tween 80 and tyrosine are hydrolysed. Lysine decarboxylase and the Voges-Proskauer reaction are positive. Negative for DNase, gluconate oxidation, indole production, methyl red test, $o$ nitrophenyl- $\beta$-D-galactopyranosidase, ornithine decarboxylase and urease. $\mathrm{H}_{2} \mathrm{~S}$ is not produced from thiosulfate. The following substrates are utilized for growth: acetate, Lalanine, ethanol, fumarate, glucose, L-glutamate, glycerol, L-histidine, lactate, malate, maltose, D-mannose, propionate, pyruvate, L-serine, succinate, sucrose and trehalose. 
Table 1. Phenotypic characteristics that differentiate strain $E 4 A 9^{\top}$ from other related members of the family Erythrobacteraceae

Strains/taxa: 1, strain E4A9 ${ }^{\mathrm{T}}$; 2, Altererythrobacter (Yoon et al., 2005b; Kwon et al., 2007); 3, Erythrobacter (Shiba \& Simidu, 1982; Yurkov et al., 1994; Denner et al., 2002; Yoon et al., 2003, 2004a, 2005a; Ivanova et al., 2005); 4, Erythromicrobium (Yurkov et al., 1994; Rainey et al., 2003); 5, Porphyrobacter (Fuerst et al., 1993; Hanada et al., 1997; Hiraishi et al., 2002; Rainey et al., 2003; Yoon et al., 2004b, 2006). Data refer to all species within the genera. +, Positive; -, negative; $(+)$ and $(-)$, positive or negative results, respectively, reported for half or more species, but no data available for the others; NA, no data available; NA (-), negative results reported for some species, but no data available for most species; $\mathrm{v}$, variable reaction; $\mathrm{v}(+)$ and $\mathrm{v}(-)$, variable, but more than half of the species display positive or negative results, respectively.

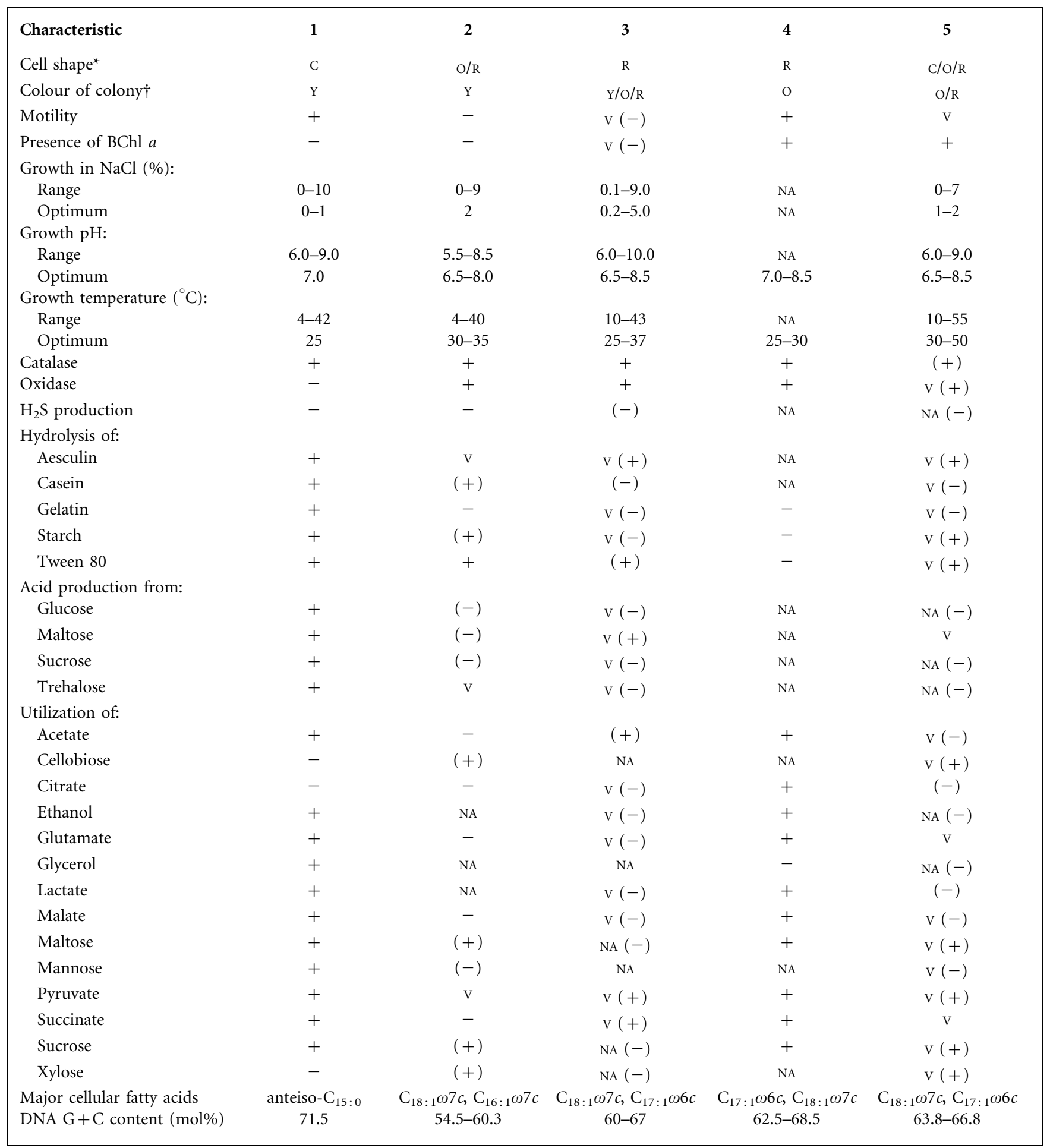

${ }^{*} \mathrm{C}$, Cocci; O, oval; R, rod.

$\dagger$, Yellow; O, orange; R, red. 
The following compounds are not utilized as sole carbon sources: L-arabinose, L-arginine, L-aspartate, cellobiose, citrate, L-cysteine, formate, D-fructose, D-galactose, glycine, gluconate, inositol, isoleucine, lactose, lysine, malonate, mannitol, L-methionine, raffinose, rhamnose, ribose, salicin, L-sorbitol, sorbose, L-valine and xylose. Acid is produced from: glucose, maltose, sucrose and trehalose. Susceptible to ampicillin $(10 \mu \mathrm{g})$, bacitracin $(0.04 \mathrm{U})$, cefalexin $(30 \mu \mathrm{g})$, ceftriaxone $(30 \mu \mathrm{g})$, chloramphenicol $(30 \mu \mathrm{g})$, erythromycin $(15 \mu \mathrm{g})$, gentamicin $(10 \mu \mathrm{g})$, minocycline $(30 \mu \mathrm{g})$, neomycin $(30 \mu \mathrm{g})$, novobiocin $(30 \mu \mathrm{g})$, penicillin $(10 \mu \mathrm{g})$, streptomycin $(10 \mu \mathrm{g})$ and tetracycline $(30 \mu \mathrm{g})$, but not to kanamycin $(30 \mu \mathrm{g})$, nitrofurantoin $(300 \mu \mathrm{g})$, nystatin $(100 \mu \mathrm{g})$ or tobramycin $(10 \mu \mathrm{g})$. Major fatty acids are anteiso- $\mathrm{C}_{15: 0}$, iso- $\mathrm{C}_{14: 0}$ and iso- $\mathrm{C}_{15: 0}$. The type strain, E4A9 ${ }^{\mathrm{T}}\left(=\mathrm{CGMCC} 1.6776^{\mathrm{T}}=\mathrm{JCM} 14846^{\mathrm{T}}\right)$, was isolated from a deep-sea sediment sample collected from a polymetallic nodule region in the East Pacific Ocean. The DNA G+C content of the type strain is $71.5 \pm 0.2 \mathrm{~mol} \%$ (as determined by HPLC).

\section{Acknowledgements}

We thank Jean Euzéby for his help with the specific etymology and nomenclature. This work was supported by grants from the Major State Basic Research Development Program of China (973 Program, 2004CB719604-3), the National Natural Science Foundation of China (40806066), the China Ocean Mineral Resources R\&D Association (COMRA) Special Foundation (DYXM-115-01-3-01, DYXM-115-013-02) and the Scientific Research Fund of the Second Institute of Oceanography, SOA (JT0709).

\section{References}

Balch, W. E., Fox, G. E., Magrum, L. J., Woese, C. R. \& Wolfe, R. S. (1979). Methanogens: reevaluation of a unique biological group. Microbiol Rev 43, 260-296.

Chun, J., Lee, J.-H., Jung, Y., Kim, M., Kim, S., Kim, B. K. \& Lim, Y.-W. (2007). EzTaxon: a web-based tool for the identification of prokaryotes based on $16 \mathrm{~S}$ ribosomal RNA gene sequences. Int J Syst Evol Microbiol 57, 2259-2261.

Denner, E. B. M., Vybiral, D., Kobližek, M., Kämpfer, P., Busse, H.-J. \& Velimirov, B. (2002). Erythrobacter citreus sp. nov., a yellow-pigmented bacterium that lacks bacteriochlorophyll $a$, isolated from the western Mediterranean Sea. Int J Syst Evol Microbiol 52, 1655-1661.

Felsenstein, J. (1981). Evolutionary trees from DNA sequences: a maximum likelihood approach. J Mol Evol 17, 368-376.

Fitch, W. M. (1971). Toward defining the course of evolution: minimum change for a specific tree topology. Syst Zool 20, 406-416.

Fuerst, J. A., Hawkins, J. A., Holmes, A., Sly, L. I., Moore, C. J. \& Stackebrandt, E. (1993). Porphyrobacter neustonensis gen. nov., sp. nov., an aerobic bacteriochlorophyll-synthesizing budding bacterium from fresh water. Int J Syst Bacteriol 43, 125-134.

Hanada, S., Kawase, Y., Hiraishi, A., Takaichi, S., Matsuura, K., Shimada, K. \& Nagashima, K. V. (1997). Porphyrobacter tepidarius sp. nov., a moderately thermophilic aerobic photosynthetic bacterium isolated from a hot spring. Int J Syst Bacteriol 47, 408-413.

Hiraishi, A., Yonemitsu, Y., Matsushita, M., Shin, Y. K., Kuraishi, H. \& Kawahara, K. (2002). Characterization of Porphyrobacter sanguineus sp. nov., an aerobic bacteriochlorophyll-containing bacterium capable of degrading biphenyl and dibenzofuran. Arch Microbiol 178, 45-52.

Ivanova, E. P., Bowman, J. P., Lysenko, A. M., Zhukova, N. V., Gorshkova, N. V., Kuznetsova, T. A., Kalinovskaya, N. I., Shevchenko, L. S. \& Mikhailov, V. V. (2005). Erythrobacter vulgaris sp. nov., a novel organism isolated from the marine invertebrates. Syst Appl Microbiol 28, 123-130.

Kamekura, M. \& Kates, M. (1988). Lipids of halophilic archaebacteria. In Halophilic Bacteria II, pp. 25-54. Edited by F. Rodriguez-Valera. Boca Raton: CRC Press.

Kämpfer, P., Steiof, M. \& Dott, W. (1991). Microbiological characterization of a fuel-oil contaminated site including numerical identification of heterotrophic water and soil bacteria. Microb Ecol 21, 227-251.

Kimura, M. (1980). A simple method for estimating evolutionary rates of base substitutions through comparative studies of nucleotide sequences. J Mol Evol 16, 111-120.

Kumar, S., Tamura, K. \& Nei, M. (2004). MEGA3: integrated software for Molecular Evolutionary Genetics Analysis and sequence alignment. Brief Bioinform 5, 150-163.

Kuykendall, L. D., Roy, M. A., O'Neill, J. J. \& Devine, T. E. (1988). Fatty acids, antibiotic resistance, and deoxyribonucleic acid homology groups of Bradyrhizobium japonicum. Int J Syst Bacteriol 38, 358-361.

Kwon, K. K., Woo, J.-H., Yang, S.-H., Kang, J.-H., Kang, S. G., Kim, S.-J., Sato, T. \& Kato, C. (2007). Altererythrobacter epoxidivorans gen. nov., sp. nov., an epoxide hydrolase-active, mesophilic marine bacterium isolated from cold-seep sediment, and reclassification of Erythrobacter luteolus Yoon et al. 2005 as Altererythrobacter luteolus comb. nov. Int J Syst Evol Microbiol 57, 2207-2211.

Lee, K.-B., Liu, C.-T., Anzai, Y., Kim, H., Aono, T. \& Oyaizu, H. (2005). The hierarchical system of the 'Alphaproteobacteria': description of Hyphomonadaceae fam. nov., Xanthobacteraceae fam. nov. and Erythrobacteraceae fam. nov. Int J Syst Evol Microbiol 55, 1907-1919.

Leifson, E. (1963). Determination of carbohydrate metabolism of marine bacteria. J Bacteriol 85, 1183-1184.

Mata, J. A., Martínez-Cánovas, J., Quesada, E. \& Béjar, V. (2002). A detailed phenotypic characterisation of the type strains of Halomonas species. Syst Appl Microbiol 25, 360-375.

Mesbah, M. \& Whitman, W. B. (1989). Measurement of deoxyguanosine/thymidine ratios in complex mixtures by high-performance liquid chromatography for determination of the mole percentage guanine + cytosine of DNA. J Chromatogr 479, 297-306.

Rainey, F. A., Silva, J., Nobre, M. F., Silva, M. T. \& da Costa, M. S. (2003). Porphyrobacter cryptus sp. nov., a novel slightly thermophilic, aerobic, bacteriochlorophyll a-containing species. Int $J$ Syst Evol Microbiol 53, 35-41.

Saitou, N. \& Nei, M. (1987). The neighbor-joining method: a new method for reconstructing phylogenetic trees. Mol Biol Evol 4, 406425.

Shiba, T. \& Simidu, U. (1982). Erythrobacter longus gen. nov., sp. nov., an aerobic bacterium which contains bacteriochlorophyll $a$. Int J Syst Bacteriol 32, 211-217.

Thompson, J. D., Higgins, D. G. \& Gibson, T. J. (1994). CLUSTAL W: improving the sensitivity of progressive multiple sequence alignment through sequence weighting, position-specific gap penalties and weight matrix choice. Nucleic Acids Res 22, 4673-4680.

Wolin, E. A., Wolin, M. J. \& Wolfe, R. S. (1963). Formation of methane by bacterial extracts. J Biol Chem 238, 2882-2886.

Xu, X.-W., Wu, Y.-H., Wang, C.-S., Oren, A., Zhou, P.-J. \& Wu, M. (2007a). Haloferax larsenii sp. nov., an extremely halophilic archaeon from a solar saltern. Int J Syst Evol Microbiol 57, 717-720. 
Xu, X.-W., Wu, Y.-H., Zhou, Z., Wang, C.-S., Zhou, Y.-G., Zhang, H.-B., Wang, Y. \& Wu, M. (2007b). Halomonas saccharevitans sp. nov., Halomonas arcis sp. nov. and Halomonas subterranea sp. nov., halophilic bacteria isolated from hypersaline environments of China. Int J Syst Evol Microbiol 57, 1619-1624.

Xu, X.-W., Wu, Y.-H., Wang, C.-S., Yang, J.-Y., Oren, A. \& Wu, M. (2008). Marinobacter pelagius sp. nov., a moderately halophilic bacterium. Int J Syst Evol Microbiol 58, 637-640.

Yoon, J.-H., Kim, H., Kim, I.-G., Kang, K. H. \& Park, Y.-H. (2003). Erythrobacter flavus sp. nov., a slight halophile from the East Sea in Korea. Int J Syst Evol Microbiol 53, 1169-1174.

Yoon, J.-H., Kang, K. H., Oh, T.-K. \& Park, Y.-H. (2004a). Erythrobacter aquimaris sp. nov., isolated from sea water of a tidal flat of the Yellow Sea in Korea. Int J Syst Evol Microbiol 54, 1981-1985.

Yoon, J.-H., Lee, M.-H. \& Oh, T.-K. (2004b). Porphyrobacter donghaensis sp. nov., isolated from sea water of the East Sea in Korea. Int J Syst Evol Microbiol 54, 2231-2235.
Yoon, J.-H., Oh, T.-K. \& Park, Y.-H. (2005a). Erythrobacter seohaensis sp. nov. and Erythrobacter gaetbuli sp. nov., isolated from a tidal flat of the Yellow Sea in Korea. Int J Syst Evol Microbiol 55, 71-75.

Yoon, J.-H., Kang, K. H., Yeo, S.-H. \& Oh, T.-K. (2005b). Erythrobacter luteolus sp. nov., isolated from a tidal flat of the Yellow Sea in Korea. Int J Syst Evol Microbiol 55, 1167-1170.

Yoon, J.-H., Kang, S.-J., Lee, M.-H., Oh, H. W. \& Oh, T.-K. (2006). Porphyrobacter dokdonensis sp. nov., isolated from sea water. Int J Syst Evol Microbiol 56, 1079-1083.

Yurkov, V., Stackebrandt, E., Holmes, A., Fuerst, J. A., Hugenholtz, P., Golecki, J., Gad'on, N., Gorlenko, V. M., Kompantseva, E. I. \& Drews, G. (1994). Phylogenetic positions of novel aerobic, bacteriochlorophyll a-containing bacteria and description of Roseococcus thiosulfatophilus gen. nov., sp. nov., Erythromicrobium ramosum gen. nov., sp. nov., and Erythrobacter litoralis sp. nov. Int J Syst Bacteriol 44, 427-434.

ZoBell, C. E. (1941). Studies on marine bacteria. I. The cultural requirements of heterotrophic aerobes. J Mar Res 4, 42-75. 